\title{
THIRD RECORD OF GLAUCOUS GULL IN ALBERTA
}

by Wayne Smith, 8220 Elbow Drive, Calgary

A second-year Glaucous Gull was seen on May 14, 1966, at Beaverhill Lake, Alberta, by Mr. and Mrs. Bruce Sparks, Kevin van Tighem, Richard Klauke, Bob Ipema, Bob Masters, some members of the Edmonton Bird Club and myself. Beaverhill Lake is about 50 miles east of Edmonton. The weather was cold, windy and rainy.

The Glaucous Gull was identified by its whiteness and by its large size. There appeared to be no grey or brown in the primaries. Sitting beside the second-year bird was a slightly smaller first-year gull. Identity of the firstyear bird remained uncertain because identifying features such as bill colour and lighter primaries were not clearly seen.
The two previous Alberta records of Glaucous Gulls in Alberta from Birds of Alberta (Salt and Wilk, 1958 and 1966) are:

1. an immature shot west of Lacombe in 1915, preservd in the Provincial Museum in Edmonton.

2. "another ... caught in a coyote trap near Youngstown in November 1940. This specimen is not preserved".

It is of interest to note that on May 8,1966 , a gull that was thought to be a Glaucous Gull or a Glaucous-winged Gull was seen within five miles of Saskatoon by J. E. Black (Saskatoon Bird Review, p. 15, June 20, 1966).

\section{SCARLET TANAGER, A SURPRISE VISITOR AT NORWAY HOUSE, MANITOBA}

by S. C. Fowke, Norway House, Manitoba

One of the joys of our bird watching at Norway House is discovering a new species in our area. We were therefore delighted this past spring with the arrival of several interesting strangers and the comparative abundance of some of the less common migrants.

On May 7, 1967 we were pleased to see an old friend from the prairies come to visit us in the "bush" in the person of a Western Meadowlark. It stayed all one evening and we had ample opportunity to study it closely. I checked and found that no one could remember seeing one here before.

Then on May 13 we were again surprised and pleased to hear that $\mathrm{Mr}$. D. Allen, Conservation Officer at Norway House, had seen a Mourning Dove. $\mathrm{He}$ and one of his workers were able to observe this bird closely several times. Again no one could remem. ber seeing this species here before.
A cold front moved in on May 18 and on May 19 there were hundreds of Harris' Sparrows, dozens of Horned Larks and numerous White-crowned and White-throated Sparrows. This influx was really a welcome change from the small numbers of each of these species that we usually see here in the spring.

The crowning touch of spring surprises came on May 29, 1967 at $9: 30$ a.m. when I sighted a male Scarlet Tanager while on a morning birding walk. When I was having a rest, I thought I saw a bit of surveyor's coloured ribbon up in a tree about 50 yards away. When I raised my binoculards to have a closer look the bird flew, and as I followed it with the glasses I knew at once that it was a male Scarlet Tanager. It landed again about 100 yards away where I observed it carefully for about one minute. I saw it yery clearly and 